\title{
ANALYSES OF RIVER OIL-SPILLS AND ACTUAL SOLVING METHODS
}

\author{
Kisfaludi-Bak Zsombor 1,2 \\ ${ }^{1}$ Transilvanian Museum Society, Cluj-Napoca, Romania, kisfaludi.zsombor@eme.ro \\ ${ }^{2}$ Technical University of Cluj-Napoca, Faculty of Civil Engineering, Department of Construcion Mechanics, \\ Cluj-Napoca, Romania, zsombor.kisfaludi@mecon.utcluj.ro
}

\begin{abstract}
Nowadays, there is an increasing emphasis on the problem of water quality. Of the many polluting effects, oil pollution is perhaps the most harmful, but its effects are being studied mostly on large seas and oceans worldwide. In the case of Transylvania and probably the entire country, pollution of rivers by oil - based on yearly occurrence - has a larger effect than that of sea pollution. Every year we observe 40-55 such water pollution events, therefore, analysis and investigation of solution methods is of great importance. This paper attempts to shed light on this issue, presenting also the method currently used by the Romanian Water Authority.
\end{abstract}

Keywords: water pollution, oil, spill-sorb, wave propagation.

\section{Introduction}

The frequency of oil contamination has increased in direct proportion to the expansion of oil production. Most of this type of water pollution occurs in the oceans near oil extraction stations. The rate of spread of oil contaminants in the oceans and open waters varies as a function of wind speed, with surface velocities averaging 1.3-1.4 \% of wind speed. [1]

In order to study the rate of spread of oil contaminants in rivers, it is necessary to know the flow characteristics and cross-sections of the river section, so we will examine the mentioned spreading velocities using a case study.

\section{Examination of the contaminated section}

In the case of water pollution emergencies, one of the most important data is the speed measured

Table 1. Long-term average yields on examined section [2]

\begin{tabular}{|l|c|c|}
\hline \multicolumn{1}{|c|}{ River } & $\begin{array}{c}\text { Cadastral num- } \\
\text { ber }\end{array}$ & $\begin{array}{c}\text { Long-term ave- } \\
\text { rage yield }\end{array}$ \\
\hline Kis-Szamos & II.1.31 & $21,2 \mathrm{~m}^{3} / \mathrm{s}$ \\
\hline Nádas & II.1.31.14 & $1,3 \mathrm{~m}^{3} / \mathrm{s}$ \\
\hline
\end{tabular}

on the water surface of the polluted river. The subject of the present analysis is the section of the Kis-Szamos (Little Somes) river (II.1.31) downstream from Cluj-Napoca, ie the section after the firth of the Nádas river. The value of the flows taken into account is the long-term average flow, which is shown in the Table 1 (the long-term/multi-year average flow of the largest tributary of the Kis-Szamos - Nádas - is also shown as a comparison).

It is important to note that the rate of water surface velocities is greatly influenced by the change in flow. In order to sense the amplitude of the changes, it is worth observing the differences between the long-term average flows and the maximum flows with different probabilitie (see Table 2).

Hydraulic simulations were also performed on the two cross sections of the studied river in the

Table 2. Ahe maximum flows of the Kis-Szamos river, after the firth of the river Nádas

\begin{tabular}{|c|c|c|}
\hline $\begin{array}{c}\text { Stereo 70 } \\
\text { Coordinates }\end{array}$ & \multicolumn{2}{|c|}{$\begin{array}{c}\mathbf{Q}_{\max } \mathbf{p} \% \\
\left(\mathbf{m}^{3} / \mathbf{s}\right)\end{array}$} \\
\hline $\mathrm{X}=393652.14$ & $1 \%$ & $515 \mathrm{~m}^{3} / \mathrm{s}$ \\
\cline { 2 - 3 } $\mathrm{Y}=588821.53$ & $0.2 \%$ & $694 \mathrm{~m}^{3} / \mathrm{s}$ \\
\hline
\end{tabular}


case of long-term average flows and $0.2 \%$ maximum flows (the occurrence period of $0.2 \%$ flow is 500 years). The elasticity constant of the river bed in the calculations is 0.040 . The modelings (Figure 1) were performed using the HEC-Ras program of the American Military Engineering, which uses a Chézy-Manning hydraulic model.

The results obtained with long-term average flows can be seen in Table 3. The surface velocities of the Kis-Szamos river, modeled with the long-term average flow on the two cross-sections, varied between $2.11-2.15 \mathrm{~m} / \mathrm{s}$.

The subject of a separate modeling was the hydrodynamic analysis of the flow occurring every 500 years (maximum flow with probability of $0.2 \%$ ) (Figure 2).

The results obtained with a maximum flow of $0.2 \%$ can be seen in Table 4 . The surface velocities of the Kis-Szamos river, modeled with a max-

Table 3. Water surface velocities calculated with long-term average flow

\begin{tabular}{|l|c|c|}
\hline & 1 & 2 \\
\hline Flow & $21.2 \mathrm{~m}^{3} / \mathrm{s}$ & $21.2 \mathrm{~m}^{3} / \mathrm{s}$ \\
\hline Width on the surface & $21.22 \mathrm{~m}$ & $22.62 \mathrm{~m}$ \\
\hline Minimum point of section & $323.04 \mathrm{~m}$ & $322.50 \mathrm{~m}$ \\
\hline Resultant level of water & $323.67 \mathrm{~m}$ & $323.11 \mathrm{~m}$ \\
\hline Active area & $9.85 \mathrm{~m}^{2}$ & $10.05 \mathrm{~m}^{2}$ \\
\hline Surface velocity & $2.15 \mathrm{~m} / \mathrm{s}$ & $2.11 \mathrm{~m} / \mathrm{s}$ \\
\hline
\end{tabular}

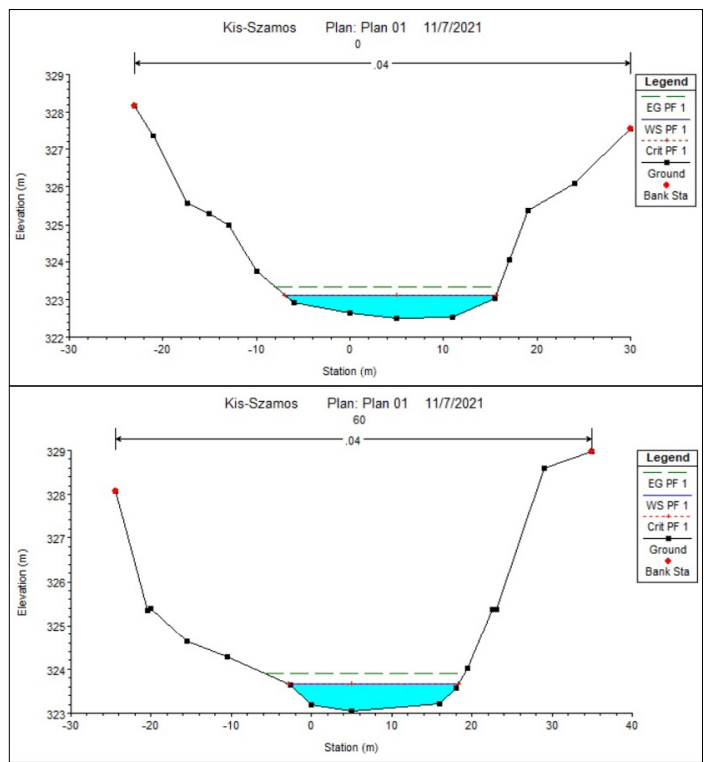

Figure 1. Water level with long-term average flow in two cross sections imum flow of $0.2 \%$ performed on the two cross sections, varied between $5.22-5.29 \mathrm{~m} / \mathrm{s}$.

\section{3. „Spill-sorb” material used in deploy- ment}

Thanks to the Romanian Water Authority, I had the opportunity to test the absorption material used in the deployments, which is manufactured by Eco Tech Service Kft. The results were presented in a previously published dissertation (Figure 3) the effect of the special material can be observed in a pictorial form below. [3]

According to the technical description issued by the manufacturer, the bonding capacity of the special material is 8-12 times its own weight in the case of general contamination. [4]

As the oil contamination is the most aggressive from the list of contaminations, we calculate with an 8-times own weight-fold own weight bonding.

Table 4. Water surface velocities calculated with a maximum flow of $0.2 \%$

\begin{tabular}{|l|c|c|}
\hline & 1 & 2 \\
\hline Flow & $694 \mathrm{~m}^{3} / \mathrm{s}$ & $694 \mathrm{~m}^{3} / \mathrm{s}$ \\
\hline Width on the surface & $48.38 \mathrm{~m}$ & $46.38 \mathrm{~m}$ \\
\hline Minimum point of section & $323.04 \mathrm{~m}$ & $322.50 \mathrm{~m}$ \\
\hline Resultant level of water & $326.82 \mathrm{~m}$ & $326.74 \mathrm{~m}$ \\
\hline Active area & $133.08 \mathrm{~m}^{2}$ & $131.13 \mathrm{~m}^{2}$ \\
\hline Surface velocity & $5.22 \mathrm{~m} / \mathrm{s}$ & $5.29 \mathrm{~m} / \mathrm{s}$ \\
\hline
\end{tabular}

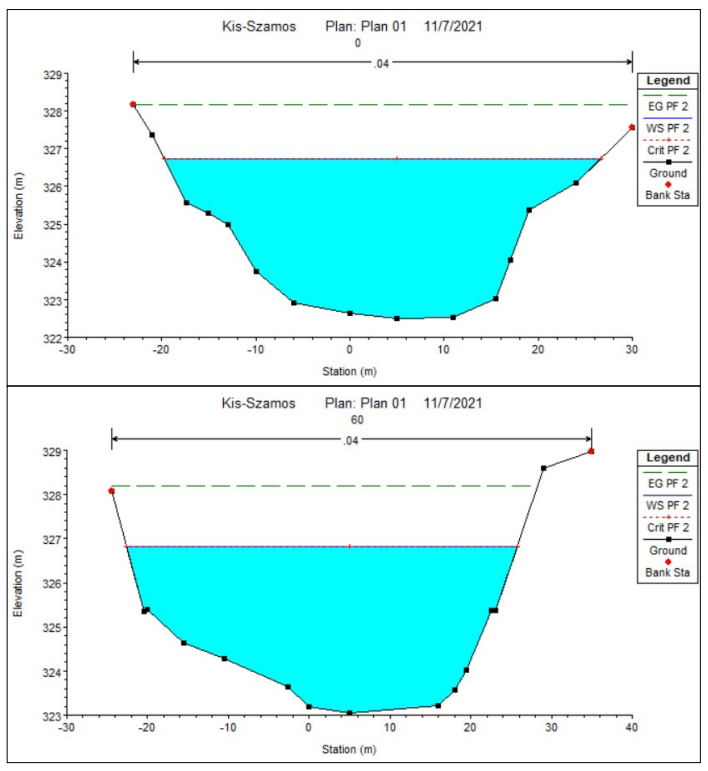

Figure 2. Water level with a maximum flow of $0.2 \%$ at the two cross sections 


\section{Spreading process, solution}

The rate of spread of the oil layer is highly dependent on the thickness of the oil layer. In the case of oil pollution in Kis-Szamos in 2013, the thickness of the oil layer was less than $1 \mathrm{~mm}$, as
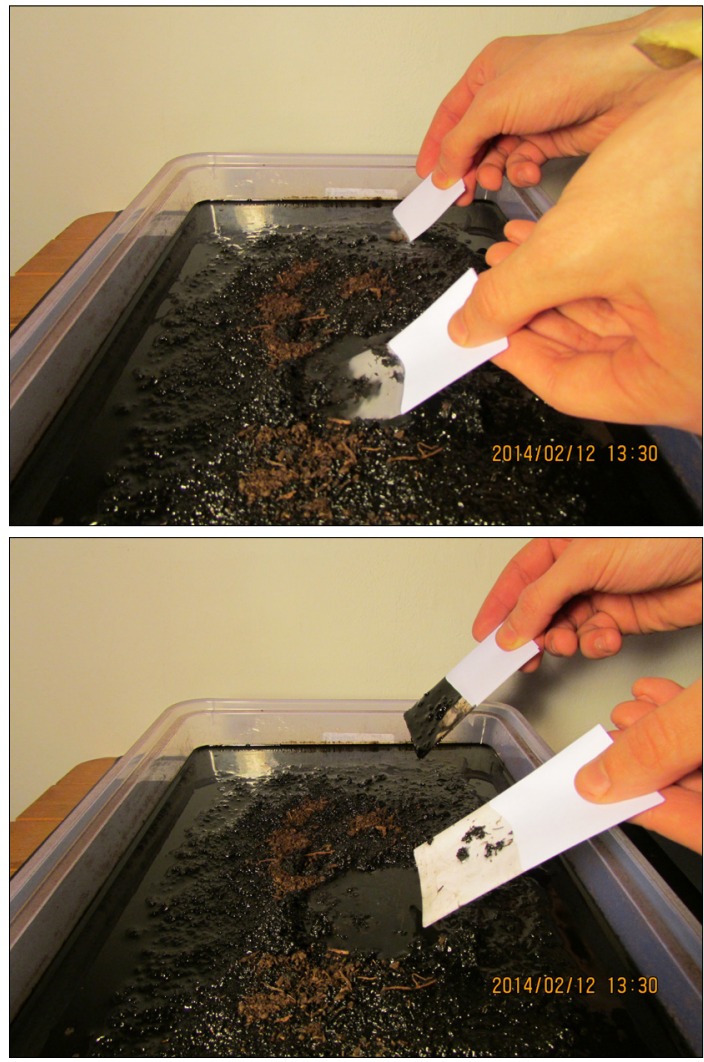

Figure 3. A Testing of absorbent Spill-sorb material (no impurities left after cutting the material sprayed on the oil surface) [3]

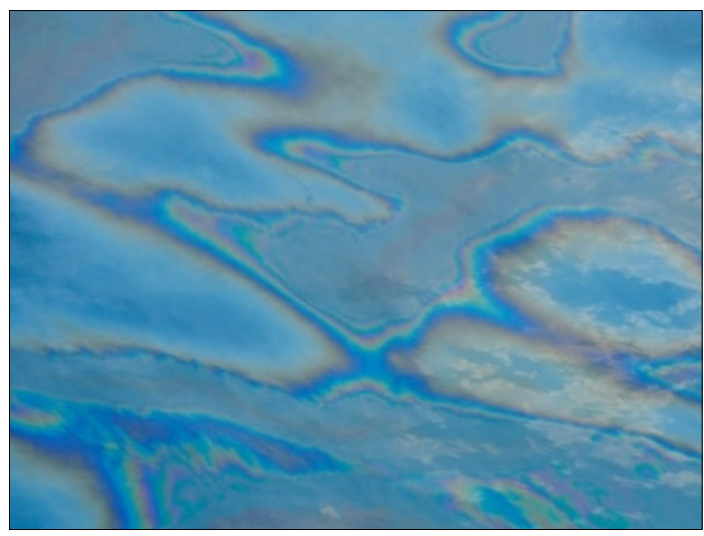

Figure 4. Water surface during oil contamination in 2013 (thick layer of oil) [5] can be seen in the image of Figure 4. on the transparency of the layer.

In the case of a similarly thin layer of oil, the rate of spread can be considered equal to the rate measured at the surface of the water. Based on these data, in the case of a long-term average yield, pollution from Cluj-Napoca reaches the mouth of the Kis-Szamos in 9 hours and 32 minutes. At a maximum yield of $0.2 \%$, the same distance will be covered in 3 hours 48 minutes.

\section{Conclusions and further plans}

In conclusion, for the treatment of oil pollution in the Cluj-Napoca section of Kis-Szamos (Somesul Mic in Romanian), similar to the case of 2013, the military and disaster management units have 9 hours 32 minutes in the case of longterm average flows, and only 3 hours 48 minutes in the case of maximum flows before the firth.

From the currently used absorbent material, it is necessary to sprinkle $106-112 \mathrm{~g} / \mathrm{m}^{2}$ of oil impurity of $1 \mathrm{~mm}$ thick layer, which can be a difficulty for such thin layers. On the positive side, the absorbent material used is able to remain on the water surface for 72 hours [4].

Further plans include more parametric studies to prepare a method to assist deployment. Currently in similar cases, logs suspended by implements are used for surface perception of the contamination, the design / analysis of special floating dams in the post-metropolitan sections is also an additional plan.

\section{Acknowledgments}

I would like to acknowledge the help of the Transylvanian Museum Society in publishing the present article.

\section{References}

[1] Buranapratheprat A., Tangjaitrong S.: Hydrodynamic Model for Oil Spill Trajectory Prediction. The Second OMISAR Workshop on Ocean Models, session 6 on Ocean Transport Models and Marine Ecosystem Models, 2000.

https://doi.org/10.1.1.551.1752

[2] Atlasul cadastrului apelor din România. Partea 1 - Date morfo-hidrografice asupre rețelei hidrografice de suprafață. Ministerul Mediului, București, 1992.

[3] Kisfaludi-Bak Zs.: Vízszennyezési vészhelyzetek kezelése, megoldási módszerei. In: Fiatal Müszakiak Tudományos Ülésszaka XIX., Kolozsvár, Románia, XIX. 2014. 237-241.

https://doi.org/10.36243/fmtu-2014.052 
[4] Eco Tech Service Kft.: Technical description SpillSorb, 5-6.

[5] Poluare cu ulei pe Someșul Mic (Oil contamination on the river Kis-Szamos) - Monitorul CJ. 2013.

http://www.monitorulcj.ro/actualitate/26973-poluare-cu-petrol-pe-raul-somesul-mic (accessed 16 July 2021) 